\title{
Petrographic composition of lignite from the Szczerców deposit, Polish Lowlands
}

\author{
Sandra Pawelec*, Barbara Bielowicz \\ AGH University of Science and Technology, Faculty of Geology, Geophysics and Environmental \\ Protection, al. Mickiewicza 30, 30-059 Kraków, Poland \\ Correspondence: spawelec@agh.edu.pl
}

Received: $27^{\text {th }}$ July, 2016

Accepted: $19^{\text {th }}$ October, 2016

\begin{abstract}
Macroscopic and microscopic composition of lignite from the Szczerców deposit belonging to the Bełchatów Lignite Mine (Polish Lowlands) has been examined. The macroscopic composition was determined according to the newest lithological classification of humic coal. On this basis, it has been shown that the main lithotypes occurring in the Szczerców deposit are the detritic and xylodetritic lignites.

The petrographic composition of the investigated lignite was determined microscopically for 11 samples. The examined lignite is predominantly composed of macerals from the huminite group. It is in the range from 75.2 to $86 \%$, including atrinite (23.1-40.7\%, averaging $28.9 \%$ ) and densinite (18.2-41.4\%, averaging $24.9 \%)$. It also demonstrated that the statistical variability of the macerals content from the huminite group in the studied lignite is very weak in all samples. In addition, the random reflectance of ulminite was measured traditionally. The results, ranging from 0.247 to $0.282 \%$, with the maximum permissible standard deviation $<0.07$, were achieved for all analysed lignite samples.
\end{abstract}

Key words: lignite, macroscopic composition, microscopic composition, Szczerców lignite deposit

\section{Introduction}

Currently, lignite is one of the primary energy resources in Poland. In addition, a slightly increasing trend in the production of lignite and electricity from this raw material can be observed in recent years. For at least three decades, the Bełchatów Lignite Mine (with the Bełchatów and Szczerców deposits) is the largest producer of lignite in Poland. The history of lignite exploitation from the Bełchatów deposit dates back to 1980 . However, it is expected that the lignite mining will end there in 2020. Currently, the lignite from the Bełchatów deposit is extracted from progressively deeper parts of the mine reaching up to $110 \mathrm{~m}$ b.s.l., where the surrounding area is located at the height of ca. $200 \mathrm{~m}$ a.s.l. Thus, it is the deepest lignite opencast mine in Poland. The lignite seams in the Bełchatów deposit are being depleted, so, they are gradually replaced by extraction from the nearby Szczerców deposit (Kasztelewicz et al. 2004). Therefore, it can be assumed that the Szczerców deposit will be the only one, which will supply the lignite to the Bełchatów power plant for at least the next 10 years. Hence, technological analysis of the lignite is crucial for assessing the suitability of this raw material for the electricity sector. Taking into account the petrographic composition of the lignite during the evaluation of its energetic properties is one of the new directions in the modern technological analysis of this raw material. This is due to the fact that individual maceral groups have different ranks of coal, and therefore the quantitative petrographic analysis provides additional information on their technological properties (Kwiecińska and Wagner 2007). 


\section{Location and shape of the Szczerców lignite deposit}

The Szczerców lignite deposit is located in the Łódź Voivodeship, southern part of the Łódź Basin, belonging to the belt of Central Polish Lowlands (Kondracki 2002). The aforementioned deposit is situated in the southern part of the Lódź Trough, within the Kleszczów Graben (Fig. 1; Narkiewicz and Dadlez 2008). This structure originated in the Laramian phase of the Alpine orogeny and was formed formed a tectonic depression, developed latitudinally in the Cretaceous and Jurassic basement, with a length of $40 \mathrm{~km}$ and a width ranging from 1.5 to $3 \mathrm{~km}$. Its average depth is around 200-300 m, up to a maximum of $500 \mathrm{~m}$ (Widera and Hałuszczak 2011). In the central part, the graben is cross-cut by a series of the NNE-SSW-trending faults. They are partially related to the Dębina Salt Dome (DSD) uplift (Hałuszczak 2004). This salt structure divided the study area into two lignite deposits, i.e. the Bełchatów deposit in the east and the Szczerców deposit in the west (Peryt and Piwocki 2004). In the area of the Szczerców deposit, the graben shape is bounded by the frame faults of the Mesozoic rocks. The graben bottom is built of both the Cretaceous and Jurassic, and Zechstein formations in the most eastern territory. In the latter case, this is genetically related to DSD, which is built of salt, marl-clay, gypsum and anhydrite (Peryt and Piwocki 2004).

The area of the Szczerców lignite deposit covers 1369.3 ha. It has a polygon shape defined by three natural and one artificial boundaries. In the east it is separated from the Bełchatów deposit the aforementioned Zechstein DSD (Fig. 1; Gotowała and Hałuszczak 2002; Hałuszczak 2004). The boundary is determined by the end of the coal seam. The northern and southern borders of the investigated area correspond to frame faults of the Kleszczów Graben (Widera and Hałuszczak 2011). In the west, the Szczerców deposit area is limited by the artificial boundary, based on the economic viability. Simplifying, the graben becomes increasingly shallower and the lignite seam is getting thinner (Fig. 1; Wagner 2001).

\section{Geology of the Szczerców lignite deposit}

The Miocene sediments in the vicinity of the Dębina Salt Dome (DSD) are located directly on the remains of the Oligocene sediments. They cover the areas, where the Upper Jurassic limestones and Upper Cretaceous gaizes are strongly karstified. These Mesozoic rocks also constitute the borders of the Kleszczów Graben and its flanks (Gotowała and Hałuszczak 2002). Gelinite lignite laminae, filling the karstic caverns and tectonic fissures, occur locally within the limestones. The thickness of this kind of lignite is up to $5 \mathrm{~cm}$ (Wagner 2001; Leśniak et al. 2002).

The Szczerców deposit belongs primarily to the tectonic type, with a symbolic involving of both the carbonate-karst and salt-karst subtypes (Kasiński and Piwocki 2002; Widera 2016a). The Neogene sediments in the examined territory have a thickness ranging from about 150 to $400 \mathrm{~m}$. They are divided into four complexes: underlying-coal complex, coal complex, clay and coal complex, and clay and sandstone complex (Fig. 1; Czarnecki et al. 1992; Gądek et al. 1999; Słomka and Wagner 2000).

The coal series begins with the underlyingcoal complex, which is represented by Neogene sandy sediments with two lignite lenses with a thickness of about $40 \mathrm{~cm}$. The overlaying medium-grained sands with numerous gravel interlayers are accompanied by lacustrine chalk intercalations within the "Poznań clays" in central and eastern parts of the Szczerców lignite deposit (Wagner 2001; Mastej et al. 2015).

The main part of the deposit is the coal complex (Fig. 1), which, due to different lignite-bearing characteristics, was divided into 
productive and non-productive subcomplexes. The non-productive subcomplex contains the fine-grained carbonaceous sands and thin lignite seams. The thickness of this complex ranges between 30 and $40 \mathrm{~m}$ with its maximum of the deposit of $100 \mathrm{~m}$ occurring in the central part of the study area (Wagner 2001). The productive subcomplex is composed of one or two lignite seams of the Early and Middle Miocene age. On the other hand, with reference to the marine stratigraphic scheme of the Paratethys area, the described productive subcomplex corresponds to the Ottnangian, Karpatian and Lower Badenian rocks (Czarnecki et al. 1992; Gądek et al. 1999; Gotowała and Hałuszczak 2002). According to the lithostratigraphic scheme for the Polish Lowlands, the aforementioned lignite seams, covering the main seam, correspond to the 2nd Lusatian and 3rd Ścinawa group of seams (Leśniak et al. 2002; Kasiński et al. 2010; Widera 2016b). The 2nd Lusatia and 3rd Ścinawa groups of seams occur together in the coal complex, and therefore they are of the greatest economic importance (Fig. 1). Their total lignite thickness in the Szczerców deposit varies from a few meters in the western part, through about 40-90 $\mathrm{m}$ in the eastern part of the deposit, to about $140 \mathrm{~m}$ in the vicinity of DSD (Czarnecki et al. 1992; Gądek et al. 1999).

The characterised above lithostratigraphic units are overlain by clay-coal and clay-sand complexes (Fig. 1). The clay-coal complex is built of clay with local carbonaceous clay and xylite rich coal from 1st Mid-Polish group of seam. The thickness of this series is up to $90 \mathrm{~m}$ in the eastern part, with a downward trend towards the west (Wagner 2001; Leśniak et al. 2002). The clay-sand complex is represented by interlayered green clays, silts and sands. The maximum thickness of these siliciclastic sediments is $80 \mathrm{~m}$. The lithostratigraphic profile in the Szczerców lignite deposits is overlain by the Quaternary cover, which thickness ranges between $0.5 \mathrm{~m}$ in the DSD area and more than $100 \mathrm{~m}$ towards the west (Fig. 1; Wagner 2001; Leśniak et al. 2002; Mastej et al. 2015).

\section{Methodology}

The study is based on core samples derived from two drillings. First, the cores were measured at drilling sites, and then the lithology of humic low rank coal, i.e. the lignite, was described using the scheme proposed by Kwiecińska and Wagner (1997). Lignite lithotypes include: detritic, xylodetritic, xylitic, detroxylitic and fusain. The lithological characterization of lignite lithotypes in the core sample included the determination of samples with different structure and a thickness greater than $10 \mathrm{~cm}$ in the case of humic and $5 \mathrm{~cm}$ for the bituminiferous (sapropelic) lignite, yellow lignite and mineral intergrowths. The lithological differences were manifested by the various share of the main petrographic components, including content of: detritus, xylites and mineral matter (Kwiecińska and Wagner 1997).

The above-mentioned lithotype units were determined in organic sediments with mineral matter content less than $40 \%$ vol. The occurrence of sapropelic lignite (bituminiferous lignite) and the content of fibrous xylites were also investigated. However, the bituminiferous lignite was categorised according to the scheme of Wagner (1996). This approach allowed identifyingthe lithotypes as elementary layers in the lignite seam, expressing in a simple way the welldefined facies of the coal-bearing mirepalaeoenvironment (Wagner 2011). In addition, carbonaceous clay, which is obviously a transitional form between lignite and clay, was also determined. Other inorganic admixtures, namely sand, tonstein, bands, pockets and thicker interbeddings of lacustrine chalk were also taken into account in this contribution. 


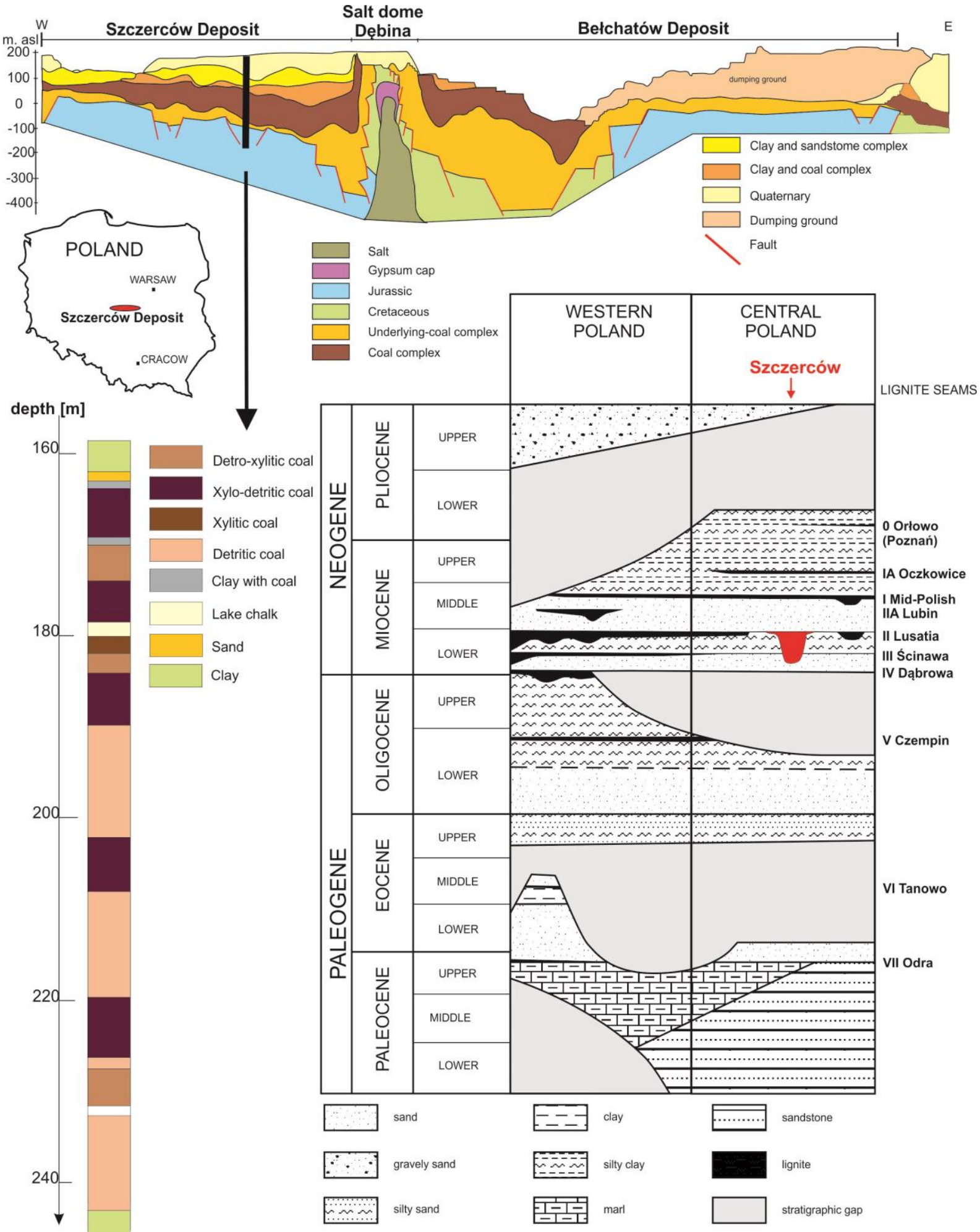

Fig.1. Location, lithological profile, synthetic profile and cross-section through the Szczerców lignite deposit (according to Czarnecki et al. 1992, Kasiński et al. 2010, modified)

The petrographic study was based on the individual samples collected in the areas of the largest lithological changes. Thus, the examined samples come from three different segments of the lignite seam, i.e. form the roof, floor and the central part of the seam. This 
method has been also statistically proven to be valid for the petrographic characteristics of lignite created in similar geological conditions (Wagner 1996; 2011). The statistical tests have not shown statistically significant differences for the most frequently used a confidence level of 0.95 . In total 11 samples were obtained for petrographic examinations from two drillings.

Polished bulk specimens were prepareted according to the Polish standard PN-ISO 74042:2005. Petrographic microscope examination was performed in both reflected white and blue light, with the use of a Zeiss Axioplan microscope Opton. Measurements of the random reflectance of ulminite $B$ was performed using a Zeiss-Opton reflectometer, in standard wavelength of $546 \mathrm{~nm}$ and immersion oil (index of refraction $\mathrm{n}=1.51$ ). Measurements of random reflectance in the studied lignite were performed on the ulminite $B$ with a mean maximum standard deviation of $0.07 \%$ (Kwiecińska and Wagner 2001a). Moreover, petrographic composition of the lignite was defined according to the ICCP classification (Sýkorovà et al. 2005). The liptinite maceral group was determined in the blue light. The analysis of maceral group content and the type of mineral matter was measured in 500 points equally spaced on the surface of preparation.

The results were statistically evaluated by calculating the average, minimum and maximum levels of the maceral group content and their standard deviations. In addition, the coefficients of variation for individual parameters were defined, and subsequently the assessment of their variability was also performed (Tab. 1; Mucha 1994).

\section{Results and discussion}

\section{Macropetrographic studies}

The coal series consists primarily of detritic lignite. On average it amounts to about $70 \%$ of thickness of the measured stratigraphic sections (Fig. 1). The detritic lignite forms layers with a thickness of 0.1 to $3.0 \mathrm{~m}$. Its structure observed in the core samples is massive and clearly directed, plane-parallel, usually accentuated by almost horizontal arrangement of xylites. This detritic lignite is fine-grained, compact and homogenous and usually moderately gelified. Locally, especially near the floor of the lignite seam, it is strongly clayey. The xylites, amounting up to $10 \%$, are generally brittle and gelified.

The average share of xylodetritic lignite in the analysed deposits is $25 \%$ vol. (Fig. 1). It occurs in the form of dark brown and hard layers, which are from 0.1 to $2 \mathrm{~m}$ thick. The xylites are also usually brittle and gelified, forming xylite intergrowthswith a thickness of up to $10 \mathrm{~cm}$.

Tab.1. The classification of statistical variability on the basis of the "V" coefficient of variation (according to Mucha 1994)

\begin{tabular}{|c|c|c|}
\hline Variability & The coefficient of variation [\%] & Color scale \\
\hline Low & $0-20$ & \\
\hline Average & $21-40$ & \\
\hline Large & $41-100$ & \\
\hline Very Large & $101-150$ & \\
\hline Extremely Large & $>150$ & \\
\hline
\end{tabular}


The detroxylitic and xylitic lignites are minor components of the seam and their average share is about $3 \%$ and $2 \%$, respectively. Taking into account their workability, the aforementioned lignite lithotypes are characterised by favourable parameters (Wagner 2001; Bielowicz 2012). Contrarily, the share of fibrous xylites is low. It is very important in the process of its mechanical grinding (milling), because the fibrous xylites make great technical complications.

Based on stratigraphic sections, it has been shown that the main lithological component of the carbonaceous series is humic lignite. Sapropelic The bituminiferous lignite (sapropelic lignite), characterised by its yellowish colour, is a minor component of the examined coal complex, reaching not more than $3.0 \%$ its total thickness. This lignite lithotype usually occurs in the form of thin layers with a thickness in the range of 0.05$0.3 \mathrm{~m}$ among above-described lithotypes. On the other hand, the share of carbonaceous clays in the coal series has also been determined in this research. Their average share is insignificant, i.e. less than $2 \%$ being interlayered with coal bands as thin layers with a thickness of 0.1 to $0.4 \mathrm{~m}$.

\section{Micropetrographic studies}

The current used petrographic classification of ortho-lignites (soft brown coals) is based on the division into three genetic maceral groups: huminite, liptinite and inertinite. These groups are determined on the basis of their macroscopic appearance, i.e. particle morphology and optical properties.

The petrographic composition of lignite from the Szczerców deposit includes two major components: carbonaceous matter and mineral matter. In the former case it ranges from 82.1 to $94.0 \%$, averaging $89.4 \%$; while in the latter case it is between 6.0 and $17.9 \%$, averaging $10.6 \%$ (Fig. 2, Tab. 2).

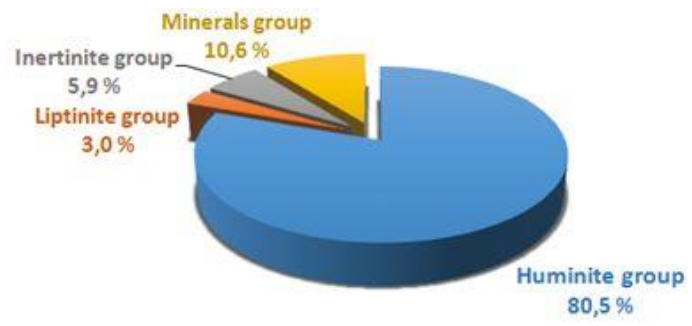

Fig.2. The average petrographic composition of lignite from the Szczerców deposit

The examined lignite is dominated by macerals of the huminite group (Fig. 2). This material originates from the lignin and cellulose rich plant parts (Kwiecińska and Wagner 2001b). Their amount ranges from 75.2 to $86.0 \%$, with average share of $80.5 \%$ (Fig. 2, Tab. 2). In addition, this maceral group is characterised by limited variability. This can be interpreted as a relatively constant petrographic composition allowing to assuming that similar composition in other parts of the Szczerców deposit can be estimated with a high probability.

The macerals from the huminite group are dominated by: attrinite (23.1-40.7\% vol., $28.9 \%$ vol. on average) and densinite (18.2$41.4 \%$ vol., $24.9 \%$ vol. on average). The sum of these macerals in each of the examined samples indicates that they are the main components of the lignite in the Szczerców deposit. Additionally textinite (1.1-21.6\% vol., $10.7 \%$ vol. on average) and ulminite (5.8-25\% vol., $13.0 \%$ vol. on average) occurred with lower values. These are undesirable components of lignite, because they are unfavourable for the process of mechanical grinding. Other macerals from the huminite group include corpohuminite $(0.9-2.3 \%$ vol., $1.4 \%$ on average $)$ and gelinite $(0.4-4.1 \%$ vol., $1.7 \%$ vol. on average). Thus, they are minor macerals in lignite from the Szczerców deposit. The results of the quantitative petrographic analysis of macerals from the huminite group confirm the occurrence of: detritic (attrinite + densinite + gelinite $>50 \%$ ), 
xylodetritic (textinite + ulminite > 25-50\%), and less common detroxylitic lignite (textinite + ulminite $\geq 50 \%$ ), which was confirmed by macropetrographic analysis. The variability of the main lithological components of lignite, i.e. xylites (textinite, ulminite) and detrital matter (mainly attrinite and densinite) is also of great importance. Attrinite is characterised by the lowest variability, which is associated with the predominantly detritic lithotype of lignite, while the variability of densinite indicates the occurrence of horizons of gelified lignite. The coefficients of variation for textinite and ulminite indicate a fairly strong and moderate variability in the amount of xylites from the Szczerców deposit, and thus their presence in lignite, although generally only in small to moderate amounts (Kwiecińska and Wagner 2001b).

Macerals from the liptinite group are microcomponents of lignite, originating from plants or microorganisms, i.e. algae, bacteria, etc. (Wagner 1996; Kwiecińska and Wagner 2001b). The share of this group macerals in the lignite from the Szczerców deposit is low and ranges from 3.3 to $11.2 \%$ vol., $5.9 \%$ vol. on average (Tab. 2). Liptodetrinite has the highest share in this group of microcomponents of lignite (1.5-6.5\% vol., 3.6\% vol. on average). Another component is resinite (0.3 to $3.8 \%$ vol., $1.3 \%$ vol. on average), occurring usually in the form of oval grains. Sporinite ranges from 0.1 to $1.5 \%$ vol., with average share of $0.7 \%$ vol. The macerals from the liptinite group that are characterised by large and extremely large variability include: cutinite (up to $0.3 \%$ vol.), fluorinite (to $0.2 \%$ vol.), terpentinite (to $0.2 \%$ vol.) and suberinite (up to $0.8 \%$ vol.). Alginite has not been found among macerals of liptinite group, while the bituminous traces, which are the main component of sapropelic lignite, have been found only in very small amounts. This suggests rare and thin interbeddings in this type of lignite and is confirmed by the petrographic sample no. 10 (drilling B; Tab. 2), which has shown a high content of macerals from the liptinite group and was classified as humic coal with interbeddings of sapropelic coal.

Macerals from the inertinite group are the remains of fungi and charred plant matter. Their large concentration is associated with the occurrence of the so-called fire horizons in the palaeo- peat bogs/mires (Kwiecińska and Wagner 2001b). The content of macerals from this group is moderately low and ranges from 1.0 to $8.5 \%$ vol., $3.0 \%$ vol. on average (Tab. 2 ). The most abundant from this group of macerals is inertodetrinite $(0.4-6.6 \%$ vol., an average of $2.0 \%$ vol.) randomly distributed in atrinite and densinite. Semifusinite, fusinite, and funginite are less common components in the abovementioned group of macerals (Tab. 2).

The high variability in the macerals share from the liptinite group has been also confirmed. However, small content of these components may indicate a good quality of the tested lignite due to the fact that liptinite produces the soot and inertinite contributes to the development of unburned fly ash (Kwiecińska and Wagner 2001b).

Petrographic studies have shown that lignite from the Szczerców deposit is relatively rich in mineral matter (ranging from 6.1 to $22.0 \%$ vol., $10.6 \%$ on average) (Tab. 2). Among them, the most abundant are the clay minerals (3.4-18.3\% vol.). They are usually scattered around attrinite and densinite. Pyrite is a common component ( 0.4 to $2.2 \%$ vol.) of lignite, indicating considerable sulphation of lignite. Quartz is less common and occurs in the form of sand admixtures. No major petrographic clusters of calcite, the major component of lacustrine chalk, have been found. Instead of this, a scattered calcite grains have been observed. The content of mineral matter in the tested drillings is characterised by average variability. Therefore, the mineral content of lignite, i.e. its ash content, for the 
Tab.2. Petrographic composition and the results of statistical analysis of variability obtained for macerals and maceral groups from the Szczerców deposit

\begin{tabular}{|c|c|c|c|c|c|c|c|c|c|c|c|c|c|c|c|c|}
\hline & \multicolumn{11}{|c|}{ Petrographic sample } & \multirow{2}{*}{\multicolumn{5}{|c|}{ Statistical analysis }} \\
\hline & \multicolumn{4}{|c|}{ Drilling A } & \multicolumn{7}{|c|}{ Drilling B } & & & & & \\
\hline & 1 & 2 & 3 & 4 & 5 & 6 & 7 & 8 & 9 & 10 & 11 & \multirow[t]{2}{*}{ 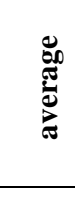 } & \multirow[t]{2}{*}{ 䇆 } & \multirow[t]{2}{*}{ } & \multirow[t]{2}{*}{$\frac{\vec{t}}{\mathrm{E}}$} & \multirow[t]{2}{*}{$\mathbf{V}$} \\
\hline Macerals & & & & & & & & & & & & & & & & \\
\hline Textinite & 3.1 & 17.0 & 21.6 & 8.8 & 5.0 & 1.1 & 20.3 & 12.7 & 9.9 & 10.1 & 8.5 & 10.7 & 1.1 & 21.6 & 6.7 & 62.3 \\
\hline Ulminite & 25.0 & 9.9 & 6.4 & 15.7 & 17.3 & 13.0 & 9.4 & 14.7 & 10.2 & 15.3 & 5.8 & 13.0 & 5.8 & 25.0 & 5.5 & 42.5 \\
\hline Atrinite & 26.5 & 23.1 & 26.3 & 24.8 & 30.5 & 40.7 & 30.2 & 34.0 & 31.7 & 27.3 & 22.4 & 28.9 & 22.4 & 40.7 & 5.3 & 18.5 \\
\hline Densinite & 28.0 & 27.1 & 18.2 & 28.1 & 23.9 & 19.1 & 18.2 & 22.1 & 22.4 & 25.3 & 41.4 & 24.9 & 18.2 & 41.4 & 6.6 & 26.5 \\
\hline Corpohuminite & 1.2 & 2.3 & 1.7 & 1.8 & 0.9 & 1.4 & 0.5 & 2.0 & 2.1 & 1.1 & 0.7 & 1.4 & 0.5 & 2.3 & 0.6 & 41.8 \\
\hline Gelinite & 1.9 & 2.0 & 1.0 & 0.7 & 1.9 & 4.0 & 1.0 & 0.4 & 0.6 & 0.8 & 4.1 & 1.7 & 0.4 & 4.1 & 1.3 & 76.3 \\
\hline$\sum$ humunite & 85.6 & 81.4 & 75.2 & 80.0 & 79.6 & 79.2 & 79.6 & 86.0 & 76.8 & 79.9 & 82.9 & 80.5 & 75.2 & 86.0 & 3.3 & 4.1 \\
\hline $\begin{array}{c}\text { Fusinite }+ \\
\text { Semifusinite }\end{array}$ & 1.2 & 0.3 & 0.3 & 1.0 & 1.3 & 0.7 & 0.0 & 1.6 & 0.6 & 1.1 & 0.7 & 0.8 & 0.0 & 1.6 & 0.5 & 61.4 \\
\hline Funginite & 0.0 & 0.0 & 0.0 & 0.0 & 0.6 & 0.0 & 0.0 & 0.0 & 0.9 & 0.0 & 0.0 & 0.1 & 0.0 & 0.9 & 0.3 & 226.6 \\
\hline Inetrtodetinite & 0.4 & 2.3 & 2.4 & 1.5 & 6.6 & 1.4 & 1.0 & 1.6 & 1.8 & 1.9 & 1.4 & 2.0 & 0.4 & 6.6 & 1.6 & 79.8 \\
\hline$\sum$ intertynite & 1.5 & 2.5 & 2.7 & 2.5 & 8.5 & 2.2 & 1.0 & 3.3 & 3.3 & 3.0 & 2.0 & 3.0 & 1.0 & 8.5 & 2.0 & 66.4 \\
\hline Sporinite & 0.8 & 1.1 & 0.6 & 0.6 & 0.3 & 0.0 & 0.6 & 0.0 & 1.2 & 1.5 & 0.9 & 0.7 & 0.0 & 1.5 & 0.5 & 68.9 \\
\hline Kutinite & 0.0 & 0.1 & 0.1 & 0.0 & 0.0 & 0.0 & 0.2 & 0.0 & 0.2 & 0.3 & 0.1 & 0.1 & 0.0 & 0.3 & 0.1 & 114.9 \\
\hline Resinite & 0.9 & 2.4 & 0.4 & 0.9 & 0.9 & 0.3 & 1.3 & 1.7 & 0.3 & 3.8 & 1.2 & 1.3 & 0.3 & 3.8 & 1.0 & 81.5 \\
\hline Fluorinite & 0.1 & 0.1 & 0.0 & 0.0 & 0.1 & 0.0 & 0.2 & 0.0 & 0.0 & 0.1 & 0.0 & 0.1 & 0.0 & 0.2 & 0.1 & 126.1 \\
\hline Terpentinite & 0.0 & 0.2 & 0.0 & 0.0 & 0.0 & 0.0 & 0.1 & 0.0 & 0.0 & 0.1 & 0.1 & 0.0 & 0.0 & 0.2 & 0.1 & 151.3 \\
\hline Suberinite & 0.0 & 0.2 & 0.0 & 0.0 & 0.1 & 0.0 & 0.0 & 0.0 & 0.1 & 0.8 & 0.0 & 0.1 & 0.0 & 0.8 & 0.2 & 218.7 \\
\hline Liptodetrinite & 1.5 & 4.1 & 3.1 & 2.9 & 3.6 & 4.0 & 3.9 & 2.1 & 6.5 & 4.6 & 3.8 & 3.5 & 1.5 & 6.5 & 1.3 & 36.1 \\
\hline$\sum$ liptynite & 3.3 & 8.2 & 4.2 & 4.4 & 5.0 & 4.3 & 6.3 & 3.8 & 8.3 & 11.2 & 6.1 & 5.9 & 3.3 & 11.2 & 2.4 & 41.2 \\
\hline $\begin{array}{c}\sum \\
\text { carbonaceous } \\
\text { substance }\end{array}$ & 90.4 & 92.1 & 82.1 & 86.9 & 93.9 & 85.6 & 87.0 & 93.0 & 88.3 & 94.0 & 90.8 & 89.4 & 82.1 & 94.0 & 3.7 & 4.2 \\
\hline Quartz & 0.8 & 0.8 & 0.0 & 0.0 & 0.0 & 0.0 & 0.0 & 0.0 & 0.0 & 0.0 & 0.0 & 0.1 & 0.0 & 0.8 & 0.3 & 222.5 \\
\hline Carbonates & 0.0 & 0.0 & 6.1 & 3.7 & 1.3 & 6.5 & 3.1 & 3.3 & 0.0 & 0.0 & 0.0 & 2.2 & 0.0 & 6.5 & 2.5 & 115.2 \\
\hline Sulphidesi & 0.4 & 1.5 & 1.0 & 2.2 & 0.6 & 0.7 & 2.1 & 0.8 & 0.9 & 1.1 & 2.0 & 1.2 & 0.4 & 2.2 & 0.6 & 52.4 \\
\hline Clay minerals & 8.4 & 5.6 & 10.8 & 7.3 & 5.0 & 7.2 & 7.8 & 2.9 & 10.8 & 4.9 & 7.1 & 7.1 & 2.9 & 10.8 & 2.4 & 34.2 \\
\hline$\sum$ minerals & 9.6 & 7.9 & 17.9 & 13.1 & 6.9 & 14.4 & 13.0 & 7.0 & 11.7 & 6.0 & 9.2 & 10.6 & 6.0 & 17.9 & 3.7 & 35.2 \\
\hline
\end{tabular}

nearby regions of the deposit can be estimated with a high probability.

Based on the petrographic composition and lithological description of lignite from the Szczerców deposit, the usefulness of this raw material for clean coal technologies, primarily gasification, has been assessed. For this purpose, the classification triangle, taking into account the four phase components of lignite, i.e. the huminite, liptinite, and inertinite group 
+ mineral matter, has been used (Bielowicz 2013) (Fig. 3).. This petrographic diagram, including all maceral groups and mineral matter, allowed for the following preliminary conclusion: lignite from the Szczerców deposit can be used in the gasification process (Fig. 3; Bielowicz 2013).

\section{Average reflectance measurements}

The measurement of the average reflectance of ulminite $\mathrm{B}$ produced similar results, in the range from 0.247 to $0.282 \%$, for all the lignite samples (Tab. 3). They are comparable to the carbon content $\left(\mathrm{C}^{\mathrm{daf}}=64.3-68.6 \% \mathrm{w} / \mathrm{w}\right)$ and gross calorific value calculated as moistureand ash-free $\left(\mathrm{GCV}^{\mathrm{maf}}=2637-2933 \mathrm{kcal} / \mathrm{kg}\right)$. This indicates the occurrence of lignite in the analysed samples. Statistical analysis based on the coefficients of variation has shown small variation of this parameter in the studied deposit. This allows to estimate the average reflectance of lignite in the Szczerców deposit in the range between 0.26 and $0.27 \%$ (Tab. 3).
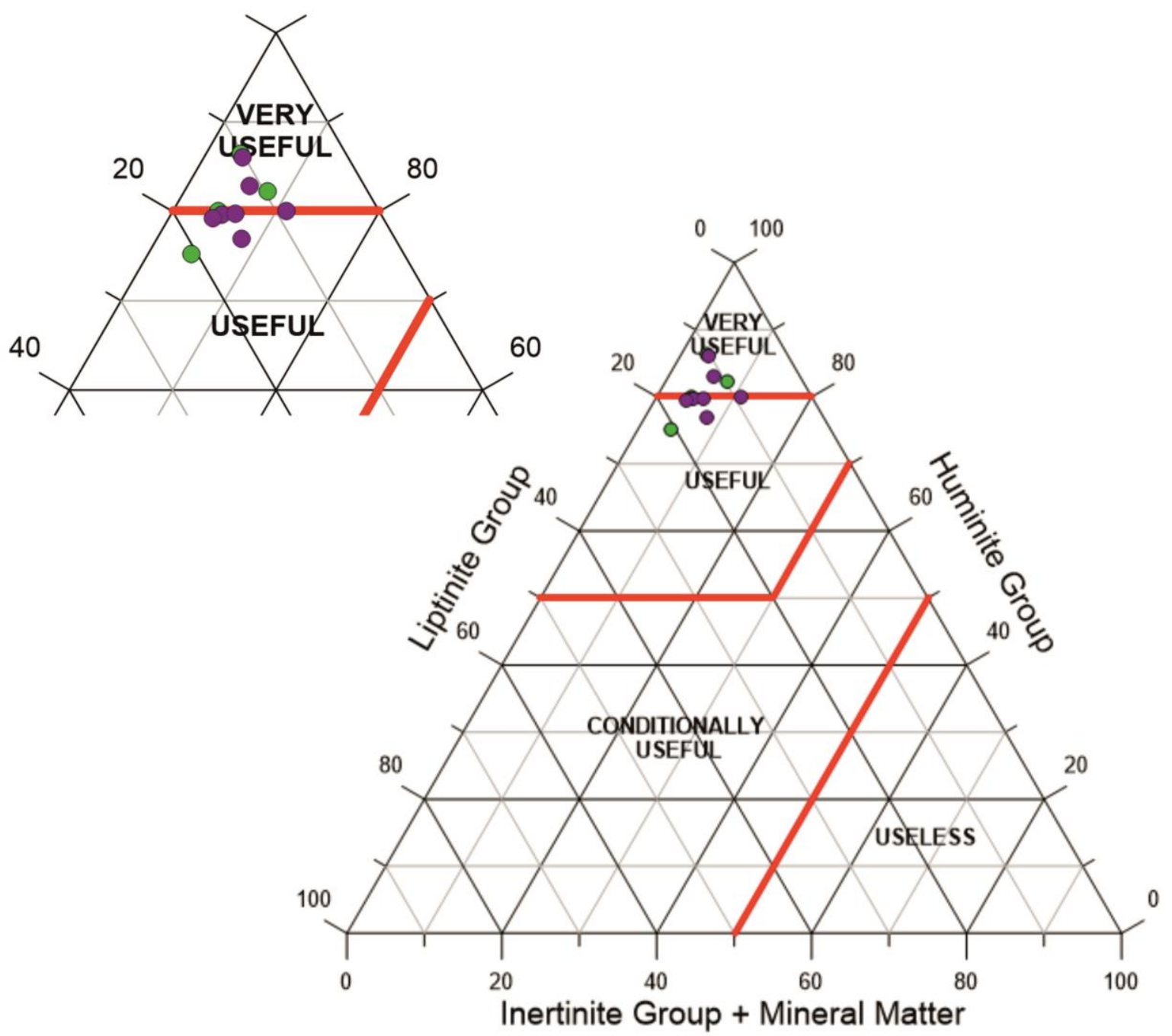

Fig.3. The classification of the usefulness of lignite from the Szczerców deposit for clean coal technologies based on its petrographic composition (according to Bielowicz 2013). Green - drillcore A, purple - drillcore B 
Tab.3. The average ulminite B reflectance values of lignite from the Szczerców deposit

\begin{tabular}{|c|c|c|c|c|}
\hline \multirow[t]{2}{*}{ Sample No. } & $\begin{array}{l}\text { The average } \\
\text { reflectance }\end{array}$ & $\begin{array}{c}\text { The average ratio } \\
\text { of the average } \\
\text { reflectance }\end{array}$ & $\begin{array}{l}\text { Standard } \\
\text { deviation }\end{array}$ & $\begin{array}{c}\text { The coefficient of } \\
\text { variation }\end{array}$ \\
\hline & [\%] & [\%] & {$[\%]$} & \\
\hline \multicolumn{5}{|c|}{ Drilling A } \\
\hline 1. & 0.247 & \multirow{4}{*}{0.26} & 0.026 & 11 \\
\hline 2. & 0.261 & & 0.034 & 13 \\
\hline 3. & 0.275 & & 0.050 & 18 \\
\hline 4. & 0.280 & & 0.037 & 13 \\
\hline \multicolumn{5}{|c|}{ Drilling B } \\
\hline 5. & 0.267 & \multirow{7}{*}{0.27} & 0.034 & 12 \\
\hline 6. & 0.264 & & 0.039 & 15 \\
\hline 7. & 0.271 & & 0.045 & 17 \\
\hline 8. & 0.270 & & 0.039 & 14 \\
\hline 9. & 0.281 & & 0.067 & 20 \\
\hline 10. & 0.282 & & 0.032 & 11 \\
\hline 11. & 0.278 & & 0.027 & 10 \\
\hline
\end{tabular}

\section{Conclusions}

The investigated lignite from the Szczerców deposit is a typical biogenic sediment of humic nature and low rank of coal, i.e. ortho-lignite (soft brown coal). This is indicated by its petrographic composition with the dominant huminite group (see Fig. 2, Tab. 2), which is characteristic of the Miocene lignite occurring in the Central European coal-bearing province (Kasiński and Piwocki 2002).

The discussed lignite contains a significant, although quantitatively variable, admixture of mineral matter (see Tab. 2). The obtained results show almost twofold higher ash content compared to that obtained on the basis of analysis contained in the geological documentation. These mineral admixtures are possibly related to the occurrence of numerous alluvial fans in the study territory (Słomka and Wagner 2000; Mastej et al. 2015).
Lignite from the Szczerców deposit is characterised by average huminite reflectance ranging from 0.26 to $0.27 \%$ (see Tab. 3), indicating its low rank. Generally, in the case of Polish lignite deposits, this parameter ranges from $0.22 \%$ in the Konin-Adamów region (e.g. Adamów, Drzewce and Ościsłowo deposits) to $0.30 \%$ in the Turów deposit (Kwiecińska and Wagner 2001; Bielowicz 2012).

\section{Acknowledgement}

This article was supported by the Polish National Science Centre under research project awarded by decision no. DEC2013/09/D/ST10/04045 and Statutory Research No 11.11.140.320. Critical remarks by reviewers are gratefully acknowledged. 


\section{References}

Bielowicz B. (2012) Scheme of new technological classification of low-rank coal according to international rules (Schemat nowej technologicznej klasyfikacji krajowego węgla brunatnego zgodnej z zasadami międzynarodowymi). Wydawnictwa Akademii GórniczoHutniczej, Kraków.

Bielowicz B. (2013) Petrographic composition of Polish lignite and its possible use in a fluidized bed gasification process. International Journal of Coal Geology, 116, 236-246.

Czarnecki L., Frankowski R., Ślusarczyk G. (1992) Syntetyczny profil litostratygraficzny rejonu złoża Bełchatów dla potrzeb Bazy Danych Geologicznych. Górnictwo Odkrywkowe, 42 (3-4), 12-22 (in Polish).

Gądek A., Frankowski F., Ślusarczyk G., Specylak-Skrzypecka J. (1999) New look at lithostratigraphic units of Bełchatów brown coal deposit (Bełchatów Field) based on updated deposit model (Nowe spojrzenie na kompleksy litostratygraficzne złoża węgla brunatnego Bełchatów (Pole Bełchatów) na podstawie zaktualizowanego modelu złoża). Górnictwo Odkrywkowe, 50(2-3), 99-105.

Gotowała R., Hałuszczak A. (2002) The Late Alpinie structural development of the Kleszczów Graben (Central Poland) as a result of a reactivation of the pre-existing, regional dislocation. EGU Stephan Mueller Special Publication Series, 1, 137-150.

Hałuszczak A. (2004) Cenozoic dynamics of the Dębina Salt Dome, Kleszczów Graben, inferred from structural features of the Tertiary-Quaternary cover. Annales Societatis Geologorum Poloniae, 74, 311318.

Kasiński J.R., Piwocki M. (2002) Low rank coals in Poland: prospection, mining, progress. [In:] (ed. J. Jureczka, M.
Podemski) Proceedings of the IV European Coal Conference. Polish Geological Institute Special Papers, 7, 17-30.

Kasiński J.R., Piwocki M., Sadowska E., Ziembińska-Tworzydło M. (2010) Lignite of the Polish Lowlands Miocene: characteristics on a base of selected profiles. Biuletyn Państwowego Instytutu Geologicznego, 439, 99-154.

Kasztelewicz Z., Klich J., Żuk S. (2004) Brown coal extracting - achievements and prospects (Wydobycie węgla brunatnego $\mathrm{w}$ Polsce - osiągnięcia i perspektywy). Agencja Wydawniczo-Poligraficzna „ART-TEKST”, 29-52.

Kondracki J. (2002) Geografia regionalna Polski. Wydawnictwa Naukowe, Warszawa (in Polish).

Kwiecińska B., Wagner M. (1997) Classification of qualitative features of brown coal from Polish deposits according to petrographical, chemical and technological criteria (Typizacja cech jakościowych węgla brunatnego z krajowych złóż według kryteriów petrograficznych i chemicznotechnologicznych dla celów dokumentacji geologicznej złóż oraz obsługi kopalń). Wydawnictwo Centrum PPGSMiE Polskiej Akademii Nauk, Kraków.

Kwiecińska B., Wagner M. (2001a) Application of reflectance in natural and technological classification of brown coal (lignite) (Możliwość zastosowania refleksyjności jako metody badawczej $\mathrm{w}$ klasyfikowaniu i technologicznej ocenie jakości węgla brunatnego. Wydawnictwo AGH, Kraków.

Kwiecińska B., Wagner M. (2001b) A petrographic atlas of brown coals (lignites) from the Polish deposits (Atlas petrograficzny węgla brunatnego). Wydawnictwo Andrzej Choczewski, Kraków.

Leśniak T., Ratajczak T., Słomka T., Wagner M. (2002) Quality of lignite from the 
exploratory boreholes based on ISO standards, together with the indication of ingredients not yet marked in KWB Bełchatów (taking into account the holes made in the framework of the project additional studies clarify the contour of the Szczerców deposit), the number of the contract 6/88/2002 (Badania jakości węgla brunatnego $\mathrm{z}$ otworów rozpoznawczych $\mathrm{i}$ piezometrycznych na podstawie norm ISO wraz $\mathrm{z}$ zaznaczeniem składników dotychczas nie oznaczonych KWB Bełchatów ( $\mathrm{z}$ uwzględnieniem otworów wykonanych w ramach projektu dodatkowych badań uściślenia konturu pola Szczerców)). Stowarzyszenie Naukowe im. Stanisława Staszica, Kraków.

Mastej W., Bartuś T., Rydlewski J. (2015) Analysis of lithofacies cyclicity in the Miocene

Coal Complex of the Bełchatów lignite deposit, south-central Poland. Geologos, 21(4), 285-302.

Mucha J. (1994) Geostatistical methods in deposit documentation (Metody geostatystyczne w dokumentowaniu złóż). Wydawnictwa Akademii GórniczoHutniczej, Kraków.

Narkiewicz M., Dadlez R. (2008) Geological regional subdivision of Poland: general guidelines and proposed schemes of subCenozoic and sub-Permian units (Geologiczna regionalizacja Polski zasady ogólne i schemat podziału w planie podkenozoicznym i podpermskim). Przegląd Geologiczny, 56(5), 391-397.

Peryt T.M., Piwocki M., ed. (2004) Geological structure of Poland (Budowa geologiczna Polski), 1(3). Państwowy Instytut Geologiczny, Warszawa.

Polish standard PN-ISO 7404-2:2005

Słomka T., Wagner M., ed. (2000) Petrological studies and sedimentological conditions of select lithologic series in Miocene from
Bełchatów lignite deposit, Poland (Charakter petrograficzny i warunki sedymentacji wybranych kompleksów litologicznych z profilu miocenu w złożu węgla brunatnego Bełchatów). Prace Geologiczne PAN, 147, Kraków.

Sýkorovà I., Pickel W., Christanis K., Wolf M., Taylor G.H., Flores D. (2005) Classification of huminite - ICCP system 1994. International Journal of Coal Geology, 62, 85-106.

Wagner M. (1996) Bituminiferous lignite from the Turów and Bełchatów brown coal deposits and its petrographic-chemical and sedimentological studies (Węgiel brunatny bitumiczny ze złóż Turów i Bełchatów w świetle badań petrograficzno-chemicznych i sedymentologicznych). Prace Geologiczne Polskiej Akademii Nauk, 143, 7-107.

Wagner M. (2001) Lithological variability of Tertiary sediments in the Szczerców lignite deposit. Proceedings of the XXIV symposium: Geology of coalbearing strata of Poland, Cracow, 101-108 (in Polish).

Wagner M. (2011) Petrologic studies and diagenetic history of coaly matter in the Podhale flysch sediments, southern Poland. Annales Societatis Geologorum Poloniae, 81, 173-183.

Widera M. (2016a) Genetic classification of Polish lignite deposits: A review. International Journal of Coal Geology, 158, 107-118.

Widera M. (2016b) Characteristics and origin of deformation structures within lignite seams - a case study from Polish opencast mines. Geological Quarterly, 60(1), 181191.

Widera M., Hałuszczak A. (2011) Stages of the Cenozoic tectonics in central Poland: examples from selected grabens. Zeitschrift der Deutschen Gesellschaft für Geowissenschaften, 162, 203-214. 